\title{
Bartosz Stopel Rozbrajając Walczące słowa Judith Butler
}

ABSTRACT. Stopel Bartosz, Rozbrajając "Walczące słowa” Judith Butler [Disarming Judith Butler's Excitable Speech]. „Przestrzenie Teorii" 17. Poznań 2012, Adam Mickiewicz University Press, pp. 63-78. ISBN 978-83-232-2449-5. ISSN 1644-6763.

The aim of this essay is to attempt to engage in polemics with the theory of hate speech endorsed by Judith Butler in her book Excitable Speech. The text will try to show that the Butlerian strategy of textualization of hate speech. If it is understood as a main tool of fighting with injurious speech, fails and, in fact, hinders this fight. The argument will touch both upon the theory and its practical application. On the theoretical level, the deconstruction of J.L. Austin's speech acts by Butler, along with a similar, earlier treatment of Austin by Derrida, will be criticized. In terms of practice, it will be attempted to view some of the recent, controversial events concerning hate speech through the lens of Butler's theory, and to show the inadequacies of treating her theory as an effective tool of fighting injurious utterances.

W swojej słynnej rozprawie Walczace słowa Judith Butler podejmuje się analizy mechanizmów powstawania i funkcjonowania mowy nienawiści, dokonując jednocześnie oceny różnych metod oporu wobec niej, przyjmuje konsekwentnie podczas całej dyskusji perspektywę dekonstrukcyjną, opierając się w dużej mierze na „krytycznym rozwinięciu” teorii aktów mowy J.L. Austina przez Jacques’a Derridę. Począwszy od nawiązania do austinowskiej koncepcji performatywów, tj. takich wypowiedzi, których samo wygłoszenie powoduje konkretne skutki, takich, które same są czynami, Butler wydaje się skłaniać ku wizji języka jako bytu autonomicznego:

Kiedy mówimy, że zostaliśmy zranieni przez język, jakiego typu twierdzenie wygłaszamy? Przypisujemy językowi sprawczość, władzę ranienia, stawiając siebie w pozycji obiektów jego krzywdzącej trajektorii. Utrzymujemy, że język działa, i to działa przeciwko nam $[. . .]^{2}$.

Owa przypisywana językowi moc sprawcza stanowi sedno myślenia Butler o mowie nienawiści i jest jednocześnie wyrazem odejścia od austinowskiej teorii. Bowiem, krytykując Austina za stwierdzenie, że znaczenie i siła danej illokucji zależą od „całościowej sytuacji” aktu mowy, Butler próbuje wskazać na niemożliwość precyzyjnego ustalenia ram owej sytuacji, a więc na naturalną płynność i tymczasowość poszczególnych

1 J. Butler, Walczace stowa. Mowa nienawiści i polityka performatywna, przeł. A. Ostolski, Warszawa 2010, s. 62.

2 Tamże, s. 9. 
wypowiedzi. Żaden akt mowy nie powstaje wyłącznie w momencie swego wypowiadania, bo zawsze jest on obarczony z jednej strony konwencją i tradycją, do której się odwołuje, a z drugiej - przyszłymi możliwościami jego użycia w nowych kontekstach. „Akt» nie jest [...] jednorazowym zdarzeniem, lecz swoistym węzłem czasowych horyzontów, zagęszczeniem iterowalności wykraczającej poza moment, który wywołuje"3. Podmiot wypowiadający dany akt, nie ma zatem pełni mocy sprawczej ani kontroli nad nim, a jego „złudzenie suwerenności”4 zanika wobec niekończącego się procesu cytowania. Innymi słowy, podmiot, którego intuicyjnie można uważać za autora danego aktu, realnie nigdy nim nie jest, ponieważ istnienie podmiotu nigdy nie jest uprzednie wobec struktur językowych. Odwołując się obszernie do myśli Althussera, Butler ma na myśli podmiot zawsze interpelowany i językowo ukonstytuowany. Można zatem wysnuć z powyższego opisu wniosek, że cały język ma charakter performatywny, że każdy akt mowy jest aktem twórczym, a każde wezwanie i nazywanie, począwszy od interpelacji podmiotu, jest zarazem kreacją. Butler zdaje się to sugerować, kiedy mówi:

o języku „myśli” się tu, a więc ustanawia na zasadzie aksjomatu jako „działanie”. Aliści myśląc o nim jako o działaniu, a więc tym, co otwiera drogę myślenia o działaniu języka, jest metaforyczne podstawienie. Ponieważ samo to sformułowanie wyraża się w języku, „działanie” języka jest nie tylko tematem tego sformułowania, lecz również tym, co ono robi ${ }^{5}$.

Zatem „owa niemożność uwolnienia się języka od własnej instrumentalności, a wręcz retoryczności, równa się jego niezdolności do zatarcia swych śladów w opowiadanej historii”, co po raz kolejny prowadzi Butler do uznania nadrzędności języka wobec podmiotu. Ów brak suwerenności i kontroli podmiotu nad wypowiedzią jest istotny również dlatego, że, jak sugeruje Butler, oznacza on permanentną niemożliwość, niefortunność wpisaną w każdy akt mowy. Według Austina performatyw był niefortunny, jeśli jego wypowiedzenie nie stwarzało zawartego w nim nowego stanu (np. wypowiedzenie słów ,jesteś aresztowany” nie pociąga za sobą faktycznego aresztowania), dla Butler każdy performatyw jest niefortunny, bo nie można kontrolować ani jego przeszłości, ani przyszłych sposobów użycia: "sukces» [performatywu] może być zawsze tylko tymczasowy”. Powodzenie danego aktu mowy jest więc możliwe tylko w ograniczonym kontekście sytuacyjnym i czasowym, a stanowiąca jego istotę cy-

\footnotetext{
3 Tamże, s. 24.

4 Tamże, s. 25.

5 Tamże, s. 15-16.

6 Tamże, s. 16.

7 Tamże, s. 63.
} 
towalność, historyczna konwencja użycia, do której odwołuje się mówiący, zwiastuje zarazem nieokreśloność jego przyszłych sposobów wykorzystania.

Owa płynność czy też tymczasowość sukcesu wszelkich aktów mowy prowadzi Butler do propozycji podjęcia pewnych działań o wymiarze politycznym względem nienawistnych aktów mowy. Problemy filozoficzne to bowiem tylko tło pracy Butler, która sama podkreśla, że „główne problemy poruszane w tej książce są tyleż retoryczne, co polityczne" jest więc stwierdzenie, że opisane wyżej poglądy są dla niej przede wszystkim uwikłane w strategię polityczną, a co sama nazywa „teorią językowej sprawczości”9, ma stanowić podstawę działań podejmowanych przeciwko mowie nienawiści będących „alternatywą wobec upartego poszukiwania lekarstwa w rozwiązaniach prawnych"10.

Czemu więc mielibyśmy unikać rozwiązań prawnych i co w zamian proponuje Butler? W pewnym sensie odpowiedzi dostarcza filozofia języka badaczki. Odwoływanie się do władzy sądu jest, według Butler, niepożądane właśnie ze względu na to, jak działa język. Chociaż Butler, jak sama mówi, nie kwestionuje jednostkowej odpowiedzialności za wypowiadanie nienawistnej mowy ${ }^{11}$, to jednak wypowiadajacy ją podmiot może jedynie zainscenizować tymczasowo autorstwo danej wypowiedzi, a nie pretendować do roli jej suwerennego władcy, który jest w pełni za nią odpowiedzialny. W rezultacie Butler sugeruje, iż uznanie, że sąd powinien regulować mowę nienawiści, zawsze obarczone jest pewnymi komplikacjami:

Jeśli pewne wypowiedzi mają być zakazane, gdzie i kiedy winno się ich ściganie rozpocząć? Gdzie i kiedy winno się skończyć? Czy nie byłoby to coś na kształt próby oskarżenia historii, której z powodu samej jej czasowości nie można postawić przed sądem? ${ }^{12}$.

Co więcej, prawna regulacja, zawsze oznacza powtarzanie mowy nienawiści; zawsze wymaga ona cytowania, kodyfikowania, utrwalania krzywdzących słów. Zamiast więc podkreślić płynność, tymczasowość i zmienność agresywnych aktów mowy, umożliwiające ich naturalną skłonność do rekontekstualizacji, a więc i rozbrojenia, działania sądów zmierzają do ich wzmocnienia, do umocnienia ułudy trwałości ich znaczeń i siły ich oddziaływania.

Ponieważ sądy nie umożliwiają skutecznej walki z mową nienawiści, Butler twierdzi, że należy posłużyć się metodami pozapaństwowymi.

8 Tamże, s. 26.

9 Tamże.

10 Tamże.

11 Tamże, s. 45.

12 Tamże, s. 61. 
Z pomocą przychodzi tu znowu wyznawana przez nią filozofia języka, która podpowiada, jak skutecznie przeciwstawić się krzywdzącej mowie. Jeśli pojedyncze akty mowy nie są tworzone przez suwerenne, autonomiczne jednostki, a stanowią odwołanie się do historii, a żadne wypowiedzi nie mają ustalonego znaczenia i mocy, ale nieustannie się przeobrażają i zmieniają w nowych kontekstach, to właśnie tę naturalną skłonność do zmiany należy podchwycić i wykorzystać. Aby skutecznie rozbroić i unieszkodliwić krzywdzącą mowę, należy więc przejąć konwencję, w ramach której operuje dana wypowiedź i przeobrazić ją, zrekontekstualizować $\mathrm{w}$ taki sposób, by utraciła swą raniącą siłę. Butler chodzi więc o zastosowanie strategii pastiszu, o zmianę oryginalnych krzywdzących kontekstów tak, aby ujawniła się nam ich stała niefortunność i tymczasowość. Chodzi zatem o „takie powtórzenie, które zerwie łączność pomiędzy aktem mowy a podtrzymującą go konwencją, tak, że powtórzenie zamiast utwierdzić jego krzywdzącą władzę, zacznie jej mieszać szyki”13.

\section{Problemy teoretyczne}

Nietrudno zauważyć, że prawie cała argumentacja Butler mająca przemawiać za przyjęciem dekonstrukcyjnej strategii walki z mową nienawiści opiera się na przyjmowanej przez nią filozofii języka. Należy przy tym dodać, że owa koncepcja funkcjonowania języka nie jest do końca jasna i nieco komplikuje całą dyskusję. Warto się tym komplikacjom przyjrzeć bliżej.

Jednym $\mathrm{z}$ niejasnych punktów w dyskusji Butler jest relacja pomiędzy podmiotem i językiem oraz konsekwencje, jakie miałyby z niej wynikać. Przy tym kwestia konsekwencji wydaje się mniej dyskusyjna. Przyjmując, że to nie mówiący podmiot jest suwerennym sprawcą i głównym celem walki z mową nienawiści, Butler zdaje się sugerować, że z formalnego oskarżenia czy osądzenia konkretnych grup czy osób należy albo uczynić sprawę drugorzędną, albo całkowicie z nich zrezygnować, ponieważ realnym polem walki staje się sam język. Tak więc, z przyjmowanej przez nią filozofii języka miałaby bezpośrednio wynikać koncepcja walki z krzywdzącą mową, opierająca się na dekonstruowaniu samych wypowiedzi.

Relacja pomiędzy podmiotem i językiem jest jednak nieco bardziej problematyczna. Z jednej strony, kiedy Butler mówi o braku suwerenności czy autonomii podmiotu, autorce można łatwo zarzucić, że jej rozumowanie mogłoby prowadzić do całkowitego uniewinnienia pojedynczych

13 Tamże, s. 29. 
osób i uznania, że winna dokonania krzywdzących aktów jest jedynie konwencja językowa. Z drugiej strony, Butler stara się uniknąć tej pułapki, wskazując na fakt, że chociaż językowo ukonstytuowany podmiot nie może być w pełni autorem wypowiedzi, ani jej władcą kontrolującym jej przeszłe i przyszłe użycia, to nadal pozostaje odpowiedzialny za wypowiadanie krzywdzących słów. Jeśli bowiem mówiący podmiot jest ustanawiany przez język, „to język jest warunkiem możliwości mówiącego podmiotu, nie zaś tylko narzędziem jego lub jej ekspresji"14 i w konsekwencji „dziejowość języka ogarnia przeszłość i przyszłość wykraczające poza historie podmiotu” 15 , ale to ten „nadmiar" historii ${ }^{16}$ sprawia, że podmiot może w ogóle zaistnieć i ma możliwość, w ograniczonym i tymczasowym charakterze, stanowienia własnej mowy.

Jeśliby zatem, w pewnym uproszczeniu, spróbować w kilku punktach opisać podstawowe założenia i wnioski obecne w jej teorii aktów mowy oraz roli języka i podmiotu, przedstawiałyby się one następująco:

a) mówiący podmiot nie sprawuje absolutnej kontroli nad swoją wypowiedzią ani nie jest jej całkowitym twórcą, ponieważ zawsze porusza się w ramach uprzednio istniejącej konwencji językowej, która zmienia się z biegiem czasu,

b) podmiot, chociaż istnieć może jedynie w strukturach językowych, nie rozpływa się w nich zupełnie; ma pewną, tymczasową kontrolę nad językiem i moc produkcji znaczeń, których wymowa może się z czasem zmieniać; podmiot jest odpowiedzialny za wypowiadany przez siebie akt mowy,

c) żaden akt mowy nie ma ustalonego raz na zawsze znaczenia; zawsze jest ono podatne na przeobrażenia, rekontekstualizacje; akty mowy zawsze wymykają się dążeniu do ich kontroli przez mówiący podmiot.

Trudno powstrzymać się od stwierdzenia, że powyższe obserwacje są dość zdroworozsądkowe i banalne; trudno wyobrazić sobie filozofa języka, który by się z nimi nie zgodził. Jest to szczególnie istotne z uwagi na fakt, iż teoretyczne wprowadzenie, które w pracy Butler poprzedza omówienie kilku kontrowersyjnych sytuacji związanych $\mathrm{z}$ mową nienawiści, jest w dużej mierze próbą nawiązania polemiki z J.L. Austinem. Butler zarzuca Austinowi zignorowanie zmiennego, płynnego charakteru wypowiedzi performatywnych (w ujęciu Butler - ich nieuniknionej niefortunności) oraz głoszenie poglądu o suwerennym podmiocie, który ma pełną moc twórczą i kontrolę nad językiem. Nie jest jednak do końca jasne, co ten pogląd miałby dokładnie znaczyć, ponieważ Butler wydaje się krytykować dość osobliwą koncepcję o całkowitej kontroli autora nad własną

\footnotetext{
14 Tamże, s. 39.

15 Tamże.

16 Tamże.
} 
wypowiedzią, której odrzucenie prowadzi ją do wniosku, że sami autorzy krzywdzącej mowy nigdy nie będą w pełni winni jej stosowania, a ostatecznie winę ponosi język, i to przede wszystkim w jego obrębie toczy się walka $\mathrm{z}$ raniącą mową. Należy tutaj zwrócić uwagę, że pogląd o całkowitej kontroli suwerennego, autonomicznego autora nad wypowiedzią, jeśli rozumieć go dosłownie, jest na tyle karykaturalny, że trudno znaleźć jakiegokolwiek współczesnego filozofa języka czy językoznawcę, który by się pod nim podpisał, a zdecydowanie bliżej mu do filozofii uprawianej przez Humpty'ego Dumpty'ego z Alicji w krainie czarów ${ }^{17}$. Trudno spierać się o to, jak rozumie to pojęcie Butler, jako że nie poświęca jego dokładnemu opisowi wiele miejsca, ale skoro ewidentnie różnicuje je $\mathrm{z}$ wymienionymi wyżej założeniami a) i b), to nie pozostaje żadna inna możliwość, jak przyjać, że rozumie ona to pojęcie dosłownie. W efekcie, potencjalnie kontrowersyjne i doniosłe rozróżnienie na językowego suwerena oraz na podmiot powołany do życia przez język stanowi fałszywą opozycję. Pierwszego z tych poglądów po prostu nie da się przypisać Austinowi, a drugi, jeśli pominąć specyficzną retorykę, nie jest w żadnej mierze odkrywczy i właściwie nie pociąga za sobą żadnych rewolucyjnych konsekwencji, podkreślając jedynie istotność językowej tradycji i nieokreśloność przyszłego użycia języka, przy jednoczesnym zachowaniu odpowiedzialności podmiotu za wypowiadane słowa.

Krytyka Austina wydaje się w tym momencie chybiona. Po pierwsze, trudno uznać, że wyznaje on nieco groteskowy pogląd o absolutnej kontroli autora nad swą wypowiedzią, czy też o suwerenności podmiotu, o ile oba te stanowiska mają być w opozycji do punktów a) i b). Jest to na tyle niejasne, że z jednej strony Butler chwali Austina za podkreślenie roli konwencji i rytuału jako warunku fortunności performatywu, a z drugiej strony wprost mówi o „wizji suwerennego podmiotu”18 zawartej w jego pracach. Po drugie, Butler zarzuca Austinowi, że niefortunność danego performatywu nie wynika wyłącznie z niespełnienia kryteriów fortunności, ale że jest ona jego konstytutywną, nieodłączną częścią. Nie da się, jak mówi Butler, wyznaczyć jasnej granicy „całościowej sytuacji mówienia"19, w ramach której realizuje się siła illokucyjna danego performatywu, ponieważ zawsze odwołuje się on do pewnej konwencji i nigdy nie może zaistnieć „w samym momencie mówienia”20. Rzecz jasna, trudno pogodzić (czego wydaje się nie dostrzegać autorka) jednoczesne przyznanie Austinowi, że podkreśla on istotność tradycji i konwencji przy ocenia-

17 D. Davidson, James Joyce and Humpty Dumpty, [w:] Truth, Language, and History, Oxford 2005, s. 147.

18 J. Butler, Walczqce stowa..., s. 60.

19 J.L. Austin, Mówienie i poznawanie, Warszawa 1993, s. 598.

20 J. Butler, Walczace słowa..., s. 11. 
niu fortunności performatywu $\mathrm{z}$ przypisaniem mu poglądu o uznaniu samego ahistorycznego momentu mówienia za wystarczający warunek owej fortunności. Zatem ten argument również nie może być wymierzony w Austina. Bardziej interesująca jest tu kwestia wyznaczenia precyzyjnych granic danego kontekstu, przy okazji której warto wrócić do sporu Derridy i Searle'a o akty mowy, bowiem argumenty Butler wydają się powtórzeniem słów tego pierwszego.

W eseju Sygnatura, zdarzenie, kontekst ${ }^{21}$ Derrida, wykładając niektóre aspekty swej filozofii języka w kluczowych momentach, odnosi się do myśli Austina. Jego krytyka Austina opiera się, podobnie jak u Butler, na uznaniu ryzyka niepowodzenia aktów mowy jako jednego z ich konstytutywnych elementów oraz na powiązanym z nim zakwestionowaniu granicy pomiędzy normalnymi wypowiedziami a wypowiedziami pasożytniczymi wobec nich (monologi aktorów na scenie, akty mowy zawarte $\mathrm{w}$ literaturze itd.). Mamy więc tu do czynienia z, podobnie jak u Butler, postawionym pytaniem dotyczącym granic pomiędzy kontekstami użycia danych wypowiedzi. Jak zauważa w swej odpowiedzi na tekst Derridy John Searle, aby w ogóle zadać jakiekolwiek pytania dotyczące natury pasożytniczych aktów mowy, trzeba już uprzednio założyć istnienie odrębnego, „poważnego” dyskursu22. W kwestii pasożytnictwa Searle powiada, że:

[f]ikcyjny dyskurs pasożytuje na nie-fikcji w takim samym sensie, w jakim definicja liczb wymiernych pasożytuje na definicji liczb naturalnych lub w jakim pojęcie pewnej stałej logicznej w danym systemie pasożytuje na innym, bo jest definiowane $\mathrm{w}$ relacji do niego. Tego rodzaju pasożytnictwo jest relacją logicznej zależności; nie zakłada ono jakiegokolwiek osądu moralnego [...] $]^{23}$.

Zatem podobnie jak w kwestii rozróżnienia pomiędzy fortunnymi a niefortunnymi aktami mowy u Butler mamy tu do czynienia z zależnością logiczną, gdzie drugie z tych pojęć „pasożytuje” na pierwszym. Można je oczywiście opisać w ten sposób, by uznać niefortunność za cechę wpisaną już $\mathrm{z}$ góry $\mathrm{w}$ pojęcie fortunności, ale jakie miałoby to znaczenie z punktu widzenia codziennego posługiwania się pojęciami udanych i nieudanych performatywów czy też fikcji i nie-fikcji? Jest to szczególnie istotne, biorąc pod uwagę nacisk, jaki Butler kładzie na polityczny i praktyczny wymiar swej teorii mowy nienawiści. Samo zadeklarowanie, że

21 J. Derrida, Sygnatura, zdarzenie, kontekst, [w:] tenże, Pismo filozofii, wybrał i przedmową opatrzył B. Banasiak, przeł. B. Banasiak, K. Matuszewski, P. Pieniążek, wyd. I, Kraków 1992, s. 225-240.

22 J. Searle, Reiterating the Differences: a Reply to Derrida, „Glyph” 1977, vol. 1, s. 205.

23 Tamże [tłumaczenie własne]. 
wszystkie akty mowy są pasożytnicze lub niefortunne nic nie będzie znaczyło, o ile nie pociąga za sobą masowej zmiany praktyki posługiwania się językiem. Trudno jednak to sobie wyobrazić, bo konwencja rozróżnienia na fikcję i niefikcję czy udany lub nieudany performatyw nie wynika z błędnej metafizyki języka ale z komunikacyjnej pragmatyki. Ponadto, tego rodzaju zmiana, o ile miałaby być czymś więcej niż pustą deklaracją, wymagałaby zaprzęgnięcia wielu instytucji, które w myśl prawa regulują używanie języka. Nie da się tego pogodzić z podejściem Butler, która ostentacyjnie odrzuca posiłkowanie się prawnymi, instytucjonalnymi rozwiązaniami. Idąc dalej, Searle słusznie wspomina, że uwagi Derridy to $\mathrm{w}$ gruncie rzeczy redefinicje pewnych pojęć będących $\mathrm{w}$ powszechnym użyciu, dodając:

Derrida utożsamia sens, w jakim pismo można nazwać pasożytującym na mowie z sensem, w jakim dyskurs fikcyjny pasożytuje na niefikcji czy też na standardowym dyskursie. Dzieli je jednak spora różnica. Rozróżnienie pomiędzy fikcją a nie-fikcją to kwestia zależności logicznej. Koncepcja fikcji po prostu nie może istnieć bez uprzedniej koncepcji poważnego dyskursu. Z drugiej strony, relacja pomiędzy pismem a mową to przygodny fakt $\mathrm{z}$ historii ludzkich języków, a nie logiczna prawda o naturze języka. W symbolice logicznej i matematycznej owa zależność przebiega dokładnie odwrotnie - forma mówiona owych symboli jest po prostu ustnie komunikowanym sposobem reprezentacji uprzednio istniejących form pisanych ${ }^{24}$.

Pomijając potencjalne pomieszanie pojęć, błędy logiczne i komunikacyjny chaos wynikające z dosłownego przyjęcia rozróżnień Derridy, różnica pomiędzy jego wizją języka a podejściem Austina to odwrócenie relacji przyczyny i skutku. Austina, jako adepta oksfordzkiej szkoły języka potocznego, badanie języka interesuje w sensie deskryptywnym, wyłącznie jako badanie pewnej konwencji społecznej, która nie ma żadnego dodatkowego wymiaru ontologicznego wykraczającego poza zbiór namacalnych, ludzkich praktyk. Stanowisko Derridy wydaje się bardziej normatywne (co unaocznia się w pismach Judith Butler, która zdaje się sugerować pewną zmianę owej praktyki językowej), jako że postuluje on pewien dodatkowy wymiar metafizyki języka, wykraczający poza codzienną praktykę i który jest wobec niej nadrzędny. W istocie, argument Derridy, tak jak i późniejsze argumenty Butler, jest w całości oparty na przeświadczeniu o pewnej konieczności ontologicznej. Według Derridy przyjęcie potocznej, austinowskiej teorii aktów mowy (a zatem i potocznej praktyki językowej, z jaką jest ona związana) jest niemożliwe, ponieważ nie istnieje klarowne i jednoznaczne rozróżnienie pomiędzy zwyczajnym a pasożytniczym stosowaniem języka:

24 Tamże, s. 207 [tłumaczenie własne]. 
Jakiż filozof, odkąd tylko pojawili się filozofowie, jakiż logik, odkąd pojawili się logicy, jakiż teoretyk kiedykolwiek odrzucił tę zasadę: w porządku pojęć (ponieważ mówimy o pojęciach, a nie o kolorach chmur lub smakach gumy do żucia), jeżeli rozróżnienie nie może być ścisłe i precyzyjne, w ogóle nie jest rozróżnieniem. Jeśli Searle otwarcie i na poważnie deklaruje, że tę zasadę należy odrzucić [...], to jego cały filozoficzny dyskurs aktów mowy upadnie bardzo gwałtownie ${ }^{25}$.

Problem w tym, że dyskurs aktów mowy Searle'a i Austina jest ściśle powiązany z codzienną praktyką językową i mógłby upaść, w sensie, o jakim mówi Derrida, tylko przy jednoczesnych głębokich przemianach codziennego stosowania języka. Tymczasem konieczność ontologiczna, na której opiera się cały argument Derridy, wydaje się, jak ujął to Searle, typowym błędem przedwittgensteinowskich filozofów, na których powołuje się Derrida, postulujących niezbędność krystalicznej struktury pojęć oraz ich jasnych granic i definicji ${ }^{26}$. Jednak, jak wykazał Wittgenstein, niezbędności wytyczania owych precyzyjnych granic przeczy sama praktyka językowa, która doskonale sobie bez nich radzi.

Searle słusznie zauważa, że przy życzliwym odczytaniu Derrida wskazuje jedynie na fakt, iż możliwość istnienia pasożytniczego dyskursu jest nieodłączną cechą języka oraz że performatywy można uznać za fortunne, tylko gdy ich treść odwołuje się do pewnych konwencji, jest cytowalna, iterowalna ${ }^{27}$, a więc jest poza kontrolą autora. Nie wiadomo jednak, dlaczego owa iterowalność miałaby kwestionować istnienie, czy istotność intencji mówiącego podmiotu. Mogłoby tak być tylko, jeżeli celem Derridy było poddanie krytyce, podobnie jak to miało miejsce w dyskusji Butler, poglądu o całkowitej kontroli autora nad własną wypowiedzią. Jednak, należy to jeszcze raz podkreślić, byłby to atak na wyimaginowanego przeciwnika, bo chyba żaden współczesny filozof języka, tym bardziej związany z teorią aktów mowy, nie głosi tak radykalnego poglądu. Nie da się zatem, przy życzliwym odczytaniu, traktować tych poglądów jako będących w sprzeczności z teorią Austina. Podobnie można skomentować krytykę Austina autorstwa Judith Butler. Stwierdzenie, że niefortunność została (logicznie) wpisana w samo pojęcie performatywu, wydaje się słuszne, ale jest truizmem, który nie podważa w żaden sposób całej teorii performatywów. Stwierdzenie, że kontekst wypowiedzi jest zmienny lub że znaczenia wypowiedzi nie da się sprowadzić do jednostkowej sytuacji jej wygłoszenia, czy też oddzielić jej wyraźnymi granicami od innych możliwości jej zastosowania, jest słuszne, ale w żadnym razie

25 J. Derrida, Limited Inc., Evanston 1988, s. 123-124 [tłumaczenie własne].

26 J. Searle, Literary Theory and Its Discontents, „New Literary History” vol. 25, no. 3, Summer, 1994, 25th Anniversary Issue (Part 1), s. 639.

27 J. Searle, Reiterating the Differences..., s. 205, 207 [tłumaczenie własne]. 
nie pozostaje w sprzeczności z teorią Austina. W efekcie, żadne z trzech wypisanych wyżej założeń Butler o języku i aktach mowy nie jest sprzeczne $\mathrm{z}$ teorią Austina, a cel jej ataków przypomina raczej karykaturę jego poglądów. Warto pamiętać, że przyjęcie strategii dekonstrukcyjnej walki z mową nienawiści miało być wynikiem przyjęcia owych, rzekomo radykalnych w porównaniu do Austina, założeń o nieistnieniu autonomii podmiotu i niefortunności wszystkich performatywów. Okazuje się jednak, że pomijając nieco agresywną retorykę, argumentacja Butler rozczarowuje, a jej stanowisko na temat języka sprowadza się do kilku ogólnie znanych (również Austinowi) prawd. Z potencjalnie kontrowersyjnych opisów o zerwaniu $\mathrm{z}$ totalną kontrolą autora $\mathrm{i}$ uśmierceniu podmiotu przez język pozostaje kilka płytkich obserwacji, którym trudno nadać polityczne czy rewolucyjne znaczenie. W efekcie ani płynność granic, ani w sumie dość banalne spostrzeżenie Butler (które również jest powtórzeniem słów Derridy) o nieuniknionym związaniu pojedynczych wypowiedzi z językową tradycją nie przemawiają na korzyść jej pomysłów z pobudek czysto teoretycznych. Filozoficzna argumentacja, która za nimi stoi jest po prostu niewystarczająca.

\section{Problemy praktyczne}

Potencjalnie błędne założenia czy też błędne rozumowanie nie przesądzają jednak w sposób decydujący o zasadności stosowania teorii Butler. Ponieważ meritum nie stanowią dla niej rozważania stricte filozoficzne, ale raczej usiłuje ona stawić czoła konkretnym problemom życia społecznego, ostateczna ocena jej koncepcji powinna być uzależniona od tego, jak jej zalecenia realizują się w praktyce; od tego, jaka jest ich wartość pragmatyczna. Niestety, w tej kwestii również można Butler wiele zarzucić. Postulat dekonstruowania mowy nienawiści nie wynika, w jej omówieniu, z jakichkolwiek pragmatycznych czy utylitarnych przesłanek, ale zdaje się pewnego rodzaju koniecznością ontologiczną, mającą swe źródła, po raz kolejny, w przyjmowanej przez dekonstrukcjonistów i poststrukturalistów filozofii języka. Właśnie przyjęcie za poststrukturalistami założenia o językowym ukonstytuowaniu się podmiotu oraz za Althusserem koncepcji interpelacji jednostki prowadzi Butler do twierdzenia o konieczności realizacji, względem mowy nienawiści, dekonstrukcjonistycznego programu. Innymi słowy, przyjęcie wyżej wymienionych założeń na temat relacji podmiotu i języka niesie ze sobą pewne zobowiązania ontologiczne prowadzące do dość radykalnych i sztywnych wniosków na temat tekstowego charakteru rzeczywistości, którym rządzi derridowska zasada „nie ma nic poza tekstem”, jednoznacznie określająca umiejsco- 
wienie walki z mową nienawiści. Należy tu zastrzec, że spór o właściwe rozumienie owych słynnych słów, tj. zarzut językowego immanentyzmu i odpowiedź apologetów Derridy o konieczności odczytywania ich jako „nie ma nic poza kontekstem”, niewiele zmienia w kwestii obrony przed mową nienawiści w ujęciu Judith Butler. Stanowisko Butler można odczytać na dwa sposoby. Nieprzychylnie, uznając jej teorię jako tekstualistyczną odmianę immanentnego idealizmu, oraz przychylnie, jako propagowanie subwersywnej wobec pozornej immanencji i idealistycznej wizji języka strategii, która unaocznia konieczność jego stałej rekontekstualizacji i reinterpretacji. Jednak w praktyce różnica pomiędzy oboma odczytaniami nie ma wielkiego znaczenia, ponieważ Butler interesuje głównie działanie w obrębie struktur językowych, marginalizujące jednostkową odpowiedzialność oraz rolę instytucji społecznych. Co prawda podkreśla ona, że koncepcja językowego formowania się podmiotu nie jest destrukcją sprawczości i podmiot nadal pozostaje odpowiedzialny za swe słowa, ale w dalszym toku jej dyskusji wyraźnie widać, że główny nacisk kładzie na walkę $\mathrm{z}$ samą wypowiedzią. Po raz kolejny więc unaocznia się tok rozumowania Butler: z jednej strony wygłasza potencjalnie radykalną tezę (językowe formowanie podmiotu), której przyjęcie oznaczałoby znaczące zmiany w ogólnym pojmowaniu mowy nienawiści i w doborze metod walki z nią; z drugiej strony dokładniejszy opis owej radykalnej tezy wskazuje na jej płytkość - nie wykracza ona poza to, co powszechnie wiadomo o języku, ubierając ogólnie znane prawdy w odpowiednią retorykę i terminologię. Kluczowy związek pomiędzy zmianą w rozumieniu, czym są raniące słowa i jak się im przeciwstawić, a nowatorskim opisem ich charakteru zanika gdzieś po drodze.

Wszystko to bardzo utrudnia ocenę skuteczności, a wręcz możliwości zastosowania strategii rozbrojenia krzywdzących aktów mowy, jako że tekstualizacja rzeczywistości $\mathrm{z}$ konieczności pomija lub marginalizuje wiele namacalnych, materialnych społecznych praktyk i instytucji odpowiedzialnych za tworzenie i odtwarzanie nienawistnej mowy (co najdobitniej widać w niejednoznacznej, na poły krytycznej postawie Butler względem sądowego rozstrzygania spraw o krzywdzących wypowiedziach), zastępując materialną rzeczywistość dyskursywnie ukonstytuowanym tekstem ${ }^{28}$. Czy próba rezygnacji z oddziaływania na konkretne, realne praktyki społeczne i chęć zastąpienia ich staraniami mającymi na celu ośmieszenie ich i ukazanie ich płynności, niedookreśloności jest w ogóle możliwa? Czy jest to efektywna strategia walki z krzywdzącymi wypowiedziami? I przede wszystkim, w jakim sensie akt mowy może zostać „rozbrojony” w rozumieniu Butler?

28 F.L. Aldama, Why the Humanities Matter, Austin 2008, s. 20. 
Aby odpowiedzieć na powyższe pytania, chciałbym przyjrzeć się głośnej sprawie sprzed kilku miesięcy, a mianowicie zarejestrowaniu przez sąd zgodnie z ustawą o partiach politycznych (czyli chronionego na równi z dobrami osobistymi) symbolu Narodowego Odrodzenia Polski - znaku „zakaz pedałowania”, stylizowanego na znak drogowy czerwonego okręgu, w którym znajdują się dwie przekreślone postaci stojące jedna za drugą. Biegli stwierdzili:

Z treści znaku, który wykorzystuje strukturę i schemat znaku drogowego, wynika jedynie zakaz kontaktów homoseksualnych w miejscach publicznych, co jest zgodne z powszechnie przyjętą obyczajowością, a wszelkie próby doszukiwania się drugiego dna są dowodem przeczulenia ${ }^{29}$.

Kontrowersyjna opinia biegłych, zaakceptowana przez sąd, wydaje się potwierdzać diagnozę Butler, która sama krytycznie odnosiła się do polegania na decyzjach sądu w kwestii mowy nienawiści, jak w przypadku krzyża podpalonego przed domem czarnoskórej rodziny w Minnesocie. Gwoli przypomnienia: Butler sugeruje, że walka z krzywdzącymi wypowiedziami drogą sądowniczą i ustawodawczą jest nieefektywna, ponieważ sądy decydujące o tym, co jest mową nienawiści, mogą owych wypowiedzi bronić pod pretekstem ochrony wolności słowa, same działając według logiki raniących słów. Co więcej, w myśl tej teorii, sądy zdają się działać na przekór naturalnej skłonności języka do rekontekstualizacji, zmiany znaczenia, wymykania się każdej próbie kontroli. Według Butler działanie sądu zawsze oznacza konieczność cytowania, utrwalania, kodyfikowania tego, czym jest mowa nienawiści, a więc $\mathrm{w}$ rzeczywistości umacnia ją, zamiast ją osłabiać. Jest to obserwacja niewątpliwie słuszna, jednak wnioski, jakie Butler z niej wyciąga, demaskują wyjątkową słabość jej strategii walki. Decyzja polskiego sądu jest szczególnie interesująca w kontekście jej teorii, ponieważ nie tylko oznacza ona właśnie instytucjonalnie potwierdzone prawo do propagowania tego, co wiele środowisk zwykło nazywać mową nienawiści, ale również w sposób jednoznaczny utrudnia jej tekstualizację i rozbrojenie, dekonstrukcję i pastisz, ponieważ każda taka próba jest równoznaczna $\mathrm{z}$ narażeniem się na zarzut znieważenia prawnie chronionego symbolu. Na szczęście nie musimy zadowalać się spekulacjami na temat siły oddziaływania strategii Butler. W kilka dni po ogłoszeniu decyzji sądu, organizacje związane z ruchem antyfaszystowskim zamieściły $\mathrm{w}$ internecie informacje o zorganizowaniu happeningu, którego celem miało być ośmieszenie i rozbrojenie, tudzież celowa prowokacja na granicy znieważenia, świeżo objętych ochroną prawną znaków NOP. Wśród zapowiadanych atrakcji nietrudno zauwa-

29 Centrum Informacji Anarchistycznej, <http://cia.media.pl/krzyz_celtycki_falanga_i zakaz_pedalowania_oficjalnie_zalegalizowane> [7.01.2012]. 
żyć elementy mogące kojarzyć się z propagowaną przez Butler taktyką dekontekstualizacji i zneutralizowania krzywdzącej siły owych znaków poprzez osadzenie ich w innym, oryginalnie niezamierzonym kontekście, jak „m.in. możliwość zrobienia sobie zdjęcia à la «zakaz pedałowania», zamalowywanie kolorowymi farbami symboli NOP-u, tęczowa siatkówka"30. W relacji opisującej, jak owa strategia tekstualizacyjna została zrealizowana podczas happeningu, możemy wyczytać, że:

wśród symboli znieważających była falanga przerobiona na penisa onanisty i hasło „Nie Organizacjom Pedofilskim (NOP)” - z przekreślonym „pedałującym” proboszczem i ministrantem. Rytualnie wycierano sobie tyłek papierem toaletowym z symbolami NOP. Działacze LGBT pozowali do zdjęć w pozycji „pedałowania” w okrągłym znaku zakazu.

Happeningowi przyglądała się grupa ok. 30 siedemnastolatków w szalikach kibicowskich, którzy wykrzykiwali hasła: „zakaz pedałowania”, „Polska cała, tylko biała itp...”. Gdy odkrzyknięto im „chodźcie z nami pedałować” - wyraźnie się zmieszali i patrzyli po sobie ${ }^{31}$.

Można oczywiście zastanawiać się, czy opisane praktyki mające być wyrazem sprzeciwu wobec mowy nienawiści, same nie inicjują kolejnej werbalnej agresji, w tym przypadku przeciwko instytucji Kościoła, niezwiązanego bezpośrednio z działalnością NOP. Co ciekawe, ze względu na zignorowanie ram instytucjonalnych określających granice dopuszczalnych wypowiedzi, Butler zdaje się pomijać w swoich rozważaniach potencjalny problem przekształcenia się samoobrony przed mową nienawiści w kolejne krzywdzące akty mowy. Jeszcze istotniejsze są tutaj ostatnie z cytowanych słów, które opisują reakcję i oddziaływanie parodystycznego happeningu. Myślę, że owo „wyraźne zmieszanie się” kilku siedemnastolatków ukazuje ostateczne fiasko strategii Butler, jeśli traktować ją jako główną (jedyną?) broń w walce z krzywdzącymi performatywami. Bo, poza wykrzyknięciem kilku skandalizujących haseł oraz zmieszaniem się kilku nastolatków, jakie jest realne oddziaływanie owej tekstualizacji na życie społeczne? Czy cokolwiek zmienia ona w układzie sił wynikającym $\mathrm{z}$ orzeczenia sądu? Czy w jakikolwiek sposób poprawia ona bezpieczeństwo uczestników publicznych happeningów mniejszości seksualnych w obliczu potencjalnych konfliktów z członkami NOP? Odpowiedzi na te pytania są jednoznacznie negatywne, a owa bezużyteczność strategii Butler jest bezpośrednim efektem tekstualizacji realnych, materialnych praktyk społecznych, a zatem oddzielenia ich sfery dyskursywnej od ma-

30 Centrum Informacji Anarchistycznej, <http://cia.media.pl/warszawa_zniewazmy_ i_wysmiejmy_zakaz_pedalowania> [7.01.2012].

31 Centrum Informacji Anarchistycznej, <http://cia.media.pl/warszawa_zniewazanie_ symboli_nop_na_pl_zamkowym> [7.01.2012]. 
terialnej i marginalizacji instytucji regulujących czy też produkujaccych mowę nienawiści.

Nadmierny nacisk na tekstualny charakter dyskursu wytwarzającego krzywdzące akty mowy prowadzi do zignorowania konkretnych działań, w których się on materializuje. Z kolei uznanie, że odpowiedzi na powyższe pytania nie odnoszą się do sedna myśli Butler i błędnie określają cel jej teorii, tym bardziej działa na jej niekorzyść. Zignorowanie faktu, że podobna do opisanej wyżej mowa nienawiści nie ogranicza się wyłącznie do nazywania, ale stanowi element szerszego programu politycznego, a także zawsze łączy się z groźbami fizycznej przemocy, jest dość niebezpieczne i, po raz kolejny, prowadzi do oderwania języka od działań, w jakie jest on zawsze uwikłany. W swej odnoszącej się do Austina dyskusji Butler opisuje dwa modele działania mowy nienawiści: illokucyjny (sama wypowiedź jest działaniem) oraz perlokucyjny (wypowiedź prowadzi do pewnych działań), skłaniając się ku temu drugiemu i uznając, że stosowanie modelu illokucyjnego jest podatne na nadużycia (jak w przypadku wyroku amerykańskiego sądu). Dziwi jednak, że przy skupieniu się na wymiarze politycznym mowy nienawiści Butler pomija kontekst, który prowadzi do powstania krzywdzącej mowy, jego rzeczywiste, niekoniecznie językowe źródła. Przypomina to właśnie oderwanie politycznej mowy nienawiści od pozajęzykowych kontekstów jej produkcji. W końcu, jak słusznie zauważa Butler, Austin podkreślał w swojej teorii aktów mowy rolę konwencji, rytuału jako jednego $\mathrm{z}$ warunków fortunności performatywu. Ale co to właściwie znaczy, że jakiś akt mowy zostaje rozbrojony przez próbę zmiany owego rytuału? Czy rzeczywiście możemy powiedzieć, że akt mowy głoszący „zakaz pedałowania” został w jakiś sposób unieważniony okrzykiem: „chodźcie z nami pedałować”? Trudno doszukać się realnych konsekwencji tego rozbrojenia, poza ewentualną zmianą samopoczucia obu stron.

Dlaczego zatem zrekontekstualizowany performatyw antyfaszystów ma taką słabą moc oddziaływania w porównaniu ze znakiem „zakazu pedałowania"? Jest to, rzecz jasna, efekt orzeczenia sądu, które obejmując ów znak ochroną, istotnie poprawiło możliwość jego propagowania i zasięg działania, ograniczając możliwości przeciwstawienia się mu. Siła języka prawnych performatywów bierze się, jak wiadomo, z możliwości zastosowania państwowego aparatu władzy, którego przymus zapewnia egzekucję prawa. Jak widać, zlekceważenie tej siły oznacza umiejscowienie się na zawsze straconej pozycji i podejmowanie nierównej walki $\mathrm{z}$ instytucjami przymusu. Butler doskonale rozumie, co stoi za wiążącą siłą performatywów prawa, ale sama nazywa tę moc „władzą krzywdzenia”32, której arbitralny charakter może stanowić potencjalnie niebez-

32 J. Butler, Walczqce stowa..., s. 76. 
pieczne narzędzie. Dziwi jednak stwierdzenie, że jeżeli prawo może czasem posłużyć za narzędzie propagowania mowy nienawiści, to należy zupełnie porzucić posługiwanie się nim. Wraca tutaj kwestia potrzeby odwoływania się do pewnych społecznych instytucji regulujących język, bez których rozbrajanie mowy nienawiści staje się pustą deklaracją, pozbawioną siły realizacji. Realny wpływ na życie społeczne samych zabiegów rekontekstualizacji wydaje się nikły.

Inny, jaskrawy przykład użycia strategii Butler do walki z raniącymi słowami, to projekcja filmu Marka Wasilewskiego pt. Opór, która miała miejsce

w ogródku piwnym na ul. Półwiejskiej w miejscu, gdzie w 2005 roku odbywał się zakazany Marsz Równości. Wtedy przeciwnicy Marszu krzyczeli w stronę jego uczestników: „Zrobimy z wami, co Hitler zrobił z Żydami”. Marek Wasilewski nagrał cheerleaderki w kolorowych strojach wykrzykujące tę samą frazę ${ }^{33}$.

Poza powtórzeniem poprzednich zarzutów dotyczących banalizacji niezwykle groźnego zjawiska, w tym przypadku dobitniej widać, że rekontekstualizacja i powtarzanie krzywdzących wypowiedzi również nie są niewinne, a stanowią zawsze reiterację raniących słów i związanych z nimi rytuałów. Jak pisze autorka artykułu:

Doszło więc tu do specyficznej zamiany, bo czy uczestnicy Marszu Równości byliby w stanie coś takiego wykrzyczeć i, idąc dalej tym tropem, czy praca Wasilewskiego nie przedstawia ich tym samym w złowrogim lustrzanym odbiciu? (Podobnie dwuznaczny wydaje się tytuł: Opór.) Ten przekaz, tak bardzo faszystowski w swojej wymowie, został więc w pewnym sensie zestetyzowany, zamieniony w barwny teledysk... To właśnie swoista banalizacja była tym, co zaniepokoiło nas najbardziej ${ }^{34}$.

Zatem argument Butler wysuwany przeciwko decyzjom sądowym w identyczny sposób odnosi się do samej strategii dekonstrukcyjnej. W obu przypadkach istnieje ryzyko, czy to powtórzenia i umocnienia nienawistnej mowy (jak w przypadku Oporu), czy sformułowania zupełnie nowego krzywdzącego aktu raniącego kolejne grono osób i instytucji (jak w przypadku antyfaszystowskiego happeningu). Co więcej, Opór unaocznia, że mało czytelna rekontekstualizacja łatwo może prowadzić do rozmycia sensu całego przekazu i nieporozumienia, z uwagi na to, że pastisz jest formą, którą wyjątkowo łatwo pomylić z poważnym traktowaniem tematu i której zrozumienie zawsze wymaga szczególnej ostrożności przy identyfikacji kontekstu i intencji.

33 I. Kowalczyk, Czy w Poznaniu pojawit się duch Beuysa?, „Obieg”, <http://www. obieg.pl/teksty/12792> [12.02.2012].

34 Tamże. 
Trudno zatem uznać, że sama tekstualizacja mogłaby być efektywnym orężem $\mathrm{w}$ walce $\mathrm{z}$ nienawistną mową. Dekonstrukcja Butler jest strategią wiecznej defensywy, która nakazuje oczekiwanie na pojawienie się krzywdzącego aktu mowy i rozbrajanie go na podyktowanych przez niego warunkach jako formę zabawy wypowiedzią. Co dziwne, Butler sama dostrzega, że raniące słowa są zawsze osadzone w pewnych rytuałach, w konkretnych praktykach, aktach fizycznej przemocy i instytucjach społecznych, ale wyraźnie marginalizuje ich znaczenie na rzecz walki z samym tekstem. Tymczasem fiasko wymienionych wyżej przykładów oporu nie tylko pokazuje, że taka postawa ignoruje rzeczywiste źródła mowy nienawiści i ignoruje jej szerszy kontekst, ale również uświadamia, że nie sposób walczyć z krzywdzącymi słowami tylko w obrębie języka czy tekstu, ponieważ nie sposób ich oddzielić od całej gamy praktyk społecznych, w których się one manifestują. Szczególnie groźna wydaje się marginalizacja walki drogą ustawodawczą i sądową, jako że przemilcza prosty fakt konieczności istnienia ram prawnych definiujących granice wolności wypowiedzi i trudność, czy też nieefektywność prowadzenia jakichkolwiek działań przeciwko mowie nienawiści poza tymi ramami. Możliwość prowadzenia akcji, takich jak happening antyfaszystowski czy projekcja filmu Wasilewskiego wydaje się oczywista w kontekście ram prawnych kształtujących współczesne zachodnie demokracje. Nie będzie jednak żadnym wysiłkiem wskazanie krajów ograniczających prawa obywatelskie, gdzie ustawodawstwo i sądy całkowicie uniemożliwiają tego rodzaju pastisz i dekontekstualizację, a przyjęcie postawy Butler nie wpływa realnie na zmianę układu sił. Można, oczywiście słusznie, zwrócić uwagę, że pastisz i subwersja, dowcip czy napisy na murach nie tylko istniały także w krajach totalitarnych, ale odgrywały tam szczególnie istotną rolę $\mathrm{w}$ walce ze znienawidzoną władzą. Tym bardziej jednak unaoczniają one bezradność ich autorów i brak możliwości realnego oddziaływania na życie społeczne, stając się podtrzymującym na duchu rozpaczliwym krzykiem wiecznej obrony. Skoro więc mowa nienawiści jest ewidentnie zakorzeniona $\mathrm{w}$ sieci społecznych praktyk, a walka z nią wymaga nie tylko stosowania pastiszu i satyry, ale konkretnych działań ustawodawczych, decyzji sądu, odpowiedniej edukacji, perswazji itd., to nasuwa się pytanie, czy w ogóle potrzebna jest nowa, dodatkowa ogólna teoria mowy nienawiści, która postuluje marginalizację wszystkich tych sfer i ograniczenie się do tekstu i pastiszu? 